\title{
Effects of glucose oxidase on the growth performance, serum parameters and faecal microflora of piglets
}

\author{
H. Tang ${ }^{1,3}$, B. Yao ${ }^{1 \#}$, X. Gao ${ }^{1 \#}$, P. Yang ${ }^{1}$, Z. Wang ${ }^{2}$ \& G. Zhang ${ }^{1,3}$ \\ ${ }^{1}$ Key Laboratory for Feed Biotechnology of the Ministry of Agriculture, Feed Research Institute, \\ Chinese Academy of Agricultural Sciences, Beijing 100081, P. R. China \\ ${ }^{2}$ National Engineering Research Centre of Biological Feed, Beijing 100081, P. R. China \\ ${ }^{3}$ Beijing Challenge Bio-technology Limited Company, Beijing 100081, P. R. China
}

(Received 1 October 2014; Accepted 19 May 2015; First published online 6 February 2016)

\begin{abstract}
Copyright resides with the authors in terms of the Creative Commons Attribution 2.5 South African Licence.
See: http://creativecommons.org/licenses/by/2.5/za

Condition of use: The user may copy, distribute, transmit and adapt the work, but must recognise the authors and the South African Journal of Animal Science.
\end{abstract}

\begin{abstract}
The experiment was conducted to investigate the effects of diets supplemented with glucose oxidase (GOD) on growth performance, serum parameters and faecal microflora of piglets. One hundred and twelve piglets ( 35 days old) were randomly assigned to two groups (four replicates per group, half male and half female, and 14 piglets per replicate) and fed a diet with or without $100 \mathrm{U}$ GOD per kg, for 35 days. Feeding GOD caused a higher average daily weight gain and feed intake, and lower feed conversion ratio (FCR) of piglets. No significant difference was observed in the reference values of serum biochemical parameters between the groups fed with or without GOD. The contents of triiodothyronine, thyroxine and growth hormone of piglets fed GOD were higher than those of the control. Moreover, GOD supplementation suppressed the concentration of faecal Salmonella. The results showed that supplementation of GOD to diets promoted growth performance, increased the contents of growth and development-related hormones, and improved the faecal microflora of growing piglets.
\end{abstract}

Keywords: Glucose oxidase, intestinal health, performance, swine

\#Corresponding authors: binyao@caas.cn; xiuhuagao@126.com

\section{Introduction}

Glucose oxidase (GOD) is a flavoprotein, which catalyses the oxidation of $\beta$-D-glucose to D-glucono- $\delta$ lactone and hydrogen peroxide $\left(\mathrm{H}_{2} \mathrm{O}_{2}\right)$, using molecular oxygen as an electron acceptor (Hatzinikolaou et al., 1996; Pluschkell et al., 1996). Glucose oxidase has several commercial applications, for example improving colour, flavour and shelf-life of food materials, removing oxygen from fruit juices and canned beverages, inhibiting the growth of pathogens and preventing rancidity in mayonnaise (Tiina et al., 1989; Malherbe et al., 2003; Seifu et al., 2004; Opwis et al., 2008; Bankar et al., 2009). Glucose oxidase can catalyse the formation of gluconic acid, and has been used as a food additive to regulate the acidity of sterilization solutions and bleaching agents in food manufacturing and as a salt in chemical components for medication (Nakao et al., 1997; Klein et al., 2002). Since 1999, GOD has been supplemented into 12 feed preparations, according to the Catalogue of Feed Additive Varieties released by the Ministry of Agriculture, People's Republic of China. There are broad prospects for GOD application in the feed industry. However, owing to low fermentation capacity and high cost, the application of GOD is limited as a feed additive. Recently, the Laboratory for Food Technology developed a new recombinant GOD with high yield $(615 \mathrm{U} / \mathrm{mL}$ and $2.5 \mathrm{~g}$ protein/L in a $3 \mathrm{~L}$ fermenter) and favourable properties (Gao et al., 2012).

Various commensal and pathogenic bacterial species are present in the gastrointestinal tracts of pigs, especially pathogenic, which represent a major source of economic loss to the pig industry worldwide (Pluske et al., 2002; Namroud et al., 2010). Of these, haemolytic enterotoxigenic, Escherichia coli, is the primary infectious agent of post-weaning colibacillosis, which provokes hypersecretory diarrhoea through the release of specific enterotoxins (Argenzio, 1992; Jones et al., 2001). Salmonella is associated with diarrhoeic piglets, with lesions more typical of enterotoxigenic diarrhoeal disease than salmonellosis (Reed et al., 1985). Schwartz (1999) remarked that most diarrhoeic piglets were associated with poor hygiene, concurrent enteric pathogens, inappropriate diets and a poor environment. It is common for haemolytic E. coli and Salmonella to appear in the faeces of pigs in increased numbers in the first week after weaning in both healthy and diarrhoeic pigs (Hampson et al., 1985). Serum biochemical parameters are good indicators of animal health. 
Numerous studies have been conducted to determine fundamental values for serum biochemical and haematological parameters of pigs. For example, triiodothyronine $\left(T_{3}\right)$ and thyroxine $\left(T_{4}\right)$ are tyrosine-based hormones produced by the thyroid gland, which are primarily responsible for regulation of the pig's metabolism (Decuypere et al., 1983; 2005). However, no experiment has been designed to evaluate the interrelationships between blood constituent changes and GOD. Therefore, the present study was designed to evaluate the effects of GOD as a feed additive on growth performance, serum parameters and faecal microflora of piglets.

\section{Materials and Methods}

The GOD preparation and millrun were provided by the Challenge Group, Beijing, People's Republic of China. All pigs used in this study were cared for in accordance with the FASS Guide for the Care and Use of Agricultural Animals in Research and Teaching (2012).

The GOD derived from Penicillium notatum was modified and produced in Pichia pastoris with a high yield (Gao et al., 2012). Recombinant GOD had optimal activity at $35-40{ }^{\circ} \mathrm{C}$ and $\mathrm{pH} 6.2$, and was stable at $\mathrm{pH} 3.0$ to 7.0 at $50^{\circ} \mathrm{C}$. The optimized recombinant GOD yielded $615 \mathrm{U} / \mathrm{mL}(2.5 \mathrm{~g}$ protein/L) in a $3 \mathrm{~L}$ fermenter. One GOD unit is defined as that quantity of enzyme that liberates $1 \mu \mathrm{mol}$ of $\mathrm{H}_{2} \mathrm{O}_{2}$ per minute under the conditions of $37^{\circ} \mathrm{C}$ and $\mathrm{pH} 5.5$.

All pigs were fed a commercial starter diet for an adaptation period of one week prior to the start of the experiment. The diets consisted of the control (no enzyme) and a control supplemented with GOD (100 U/kg diet). The control diet was formulated to meet or exceed the requirements of the Feeding Standard of Swine of the People's Republic of China (2004) and was composed of maize, soybean meal, soybean oil, extruded soybean, fermented soybean meal, fish meal, glucose, etc. (Table 1).

Table 1 Ingredient composition and nutrient contents of experimental diet (g/kg) (as fed) ${ }^{\mathrm{a}}$

\begin{tabular}{lc}
\hline Item & Content \\
\hline Ingredient & \\
$\quad$ Maize & 600.0 \\
Soybean meal & 155.0 \\
Soybean oil & 16.0 \\
Extruded soybean & 80.0 \\
Fermented soybean meal & 20.0 \\
Fish meal & 34.0 \\
Whey powder & 15.0 \\
Glucose & 40.0 \\
Premix ${ }^{\text {b }}$ & 40.0 \\
Nutrient content & \\
Digestible energy (MJ/kg) (calculated) & 14.19 \\
Crude protein & 185.0 \\
Calcium & 7.2 \\
Total phosphorus & 6.0 \\
Available phosphorus & 3.7 \\
Lysine & 13.7 \\
Methionine & 5.4 \\
Threonine & 9.0 \\
Tryptophan & 2.4
\end{tabular}

\footnotetext{
${ }^{\mathrm{a}}$ The basic diet was formulated with/without addition of glucose oxidase (100 U/kg of diet).

${ }^{\mathrm{b}}$ Premix (per kg of diet) contained 30 glysine; $10 \mathrm{~g}$ choline; $75 \mathrm{~g}$ salt; $200 \mathrm{~g} \mathrm{Ca} ; 240 \mathrm{~g}$ total P; 4500 mg Fe; 4000 mg Cu; 7500 mg Mn; 3000 mg Zn; 60 mg I; 10 mg Se; 750 mg nicotinic acid; $16 \mathrm{mg}$ folic acid; $375 \mathrm{mg}$ calcium pantothenate; $7.5 \mathrm{mg}$ biotin; $75000 \mathrm{IU}$ vitamin A; 25000 IU vitamin D; $375 \mathrm{IU}$ vitamin $\mathrm{E} ; 14 \mathrm{mg}$ vitamin $\mathrm{K} ; 37.5 \mathrm{mg}$ vitamin $\mathrm{B}_{1} ; 120 \mathrm{mg}$ vitamin $\mathrm{B}_{2} ; 78 \mathrm{mg}$, vitamin $\mathrm{B}_{6}$; $0.4 \mathrm{mg}$ vitamin $\mathrm{B}_{12}$.
} 
One hundred and twelve piglets, weaned at $21 \pm 1 \mathrm{~d}$ old, were obtained from a local livestock breeding farm in Beijing, China, and housed 14 in a pen with plastic-covered expanded metal floors. The average weight of the piglets was recorded at the end of the adaptation period. The piglets were then randomly assigned in two groups for control and treatment based on sex and bodyweight. Each group contained four pens (half male and half female), and each pen contained 14 pigs. Pigs had unlimited access to feed and water throughout the five-week study. The room temperature was initially maintained at $28^{\circ} \mathrm{C}$ on week 1 , and gradually decreased at about $1.5^{\circ} \mathrm{C}$ per week.

Bodyweight and feed intake were monitored at $d 35$ to determine average daily gain (ADG), average daily feed intake (ADFI) and feed conversion ratio (FCR). Blood samples were collected from two pigs/pen via jugular venipuncture on d 35. Samples (approximately $6 \mathrm{~mL} /$ tube) were collected into plastic tubes without anticoagulant. The blood was allowed to clot at room temperature, followed by centrifugation at 1 , $155 \times g$ for $5 \mathrm{~min}$ at room temperature. Serum was collected and stored at $-20^{\circ} \mathrm{C}$ until further analysis. The contents of albumin, globulin and total protein were determined by automatic biochemical analyser (7600; Hitachi Medical (Guangzhou) Co., Ltd., Guangzhou, China), and the coefficient of serum proteins was calculated. The concentrations of $T_{3}, T_{4}$, thyroid-stimulating hormone, growth hormone $(\mathrm{GH})$, insulin and glucagon were determined using radioimmunoassay (Hunter, 1986).

Fresh faecal samples were collected immediately after defecation from three pigs per pen on $\mathrm{d} 14$ and $\mathrm{d} 35$, and subjected to microflora analysis right away. The total counts of bacteria and E. coli and Salmonella were determined by the dilution method on LB agar (peptone $10.0 \mathrm{~g} / \mathrm{L}$, yeast power $5.0 \mathrm{~g} / \mathrm{L}, \mathrm{NaCl} 9.0 \mathrm{~g} / \mathrm{L}$, agar $15.0 \mathrm{~g} / \mathrm{L}, \mathrm{pH} 7.2$ and MacConkey agar plates (peptone $20.0 \mathrm{~g} / \mathrm{L}$, lactose $10.0 \mathrm{~g} / \mathrm{L}$, bile salt $5.0 \mathrm{~g} / \mathrm{L}, \mathrm{NaCl}$ $5.0 \mathrm{~g} / \mathrm{L}$, toluylene red $0.03 \mathrm{~g} / \mathrm{L}$, and agar $14.0 \mathrm{~g} / \mathrm{L}, \mathrm{pH} 7.1)$ ), respectively. Lactobacilli were enumerated by using MRS agar plates (peptone $10.0 \mathrm{~g} / \mathrm{L}$, beef extract $10.0 \mathrm{~g} / \mathrm{L}$, yeast powder $5.0 \mathrm{~g} / \mathrm{L}$, diammonium citrate $2.0 \mathrm{~g} / \mathrm{L}$, sodium acetate $5.0 \mathrm{~g} / \mathrm{L}$, glucose $20.0 \mathrm{~g} / \mathrm{L}$, twain $801.0 \mathrm{~mL} / \mathrm{L}, \mathrm{MgSO}_{4} .7 \mathrm{H}_{2} \mathrm{O} 0.58 \mathrm{~g} / \mathrm{L}, \mathrm{K}_{2} \mathrm{HPO}_{4} 2.0 \mathrm{~g} / \mathrm{L}$, $\mathrm{MnSO}_{4} .7 \mathrm{H}_{2} \mathrm{O} 0.25 \mathrm{~g} / \mathrm{L}$, agar $15.0 \mathrm{~g} / \mathrm{L}, \mathrm{pH} 6.8$ ). Approximately $1.0 \mathrm{~g}$ of fresh faecal sample was suspended in $99.0 \mathrm{~mL}$ of sterile $0.9 \%$ normal saline solution, vibrated for $10 \mathrm{~min}\left(35 \times \mathrm{g}, 20^{\circ} \mathrm{C}\right)$, and serially diluted $1.0 \mathrm{~mL}$ to $9.0 \mathrm{~mL}$ in the same saline solution. Dilutions of $10^{4}$ to $10^{6}(0.1 \mathrm{~mL})$ were plated on agar plates and incubated at $37{ }^{\circ} \mathrm{C}$ for $24 \mathrm{~h}$. The total counts of bacteria E. coli, Salmonella and Lactobacilli were then determined. All plates were done in triplicate, and the results were reported as cfu per gram of fresh faecal sample.

Bacterial enumeration data were transformed into lgcfu/g before statistical analysis. The sex effect was insignificant, and was excluded from the model. A pen of 14 pigs was treated as an experimental unit for growth performance data analysis, and each pig was a unit for the serum parameter analysis. The data were submitted to ANOVA using the GLM procedure of SAS (SAS, 2004). Significant differences $(P<0.05)$ were determined by Duncan's multiple range test.

\section{Results and Discussion}

The growth performance of pigs in the various groups is summarized in Table 2. No mortality was observed in this experiment. Piglets on control and treatment groups were similar in ADFI $(P>0.05)$, but showed significant differences in the final weight, ADG and FCR $(P<0.05)$. Pigs fed GOD-supplemented diet had higher ADG (382 g/d vs. $341 \mathrm{~g} / \mathrm{d})$ and lower FCR (1.76 vs. 1.94) values than those fed the control diet. The natural function of GOD is closely related to its catalytic activity. It catalyses the oxidation of $\beta$-D-glucose to gluconic acid by utilizing molecular oxygen as an electron acceptor with simultaneous production of $\mathrm{H}_{2} \mathrm{O}_{2}$ (Hatzinikolaou \& Macris, 1995). Two products of GOD hydrolysis are $\mathrm{H}_{2} \mathrm{O}_{2}$ and gluconic acid, which may act as a bacteriocide (Crueger \& Crueger, 1990; Rasiah et al., 2005; Costa et al., 2013) and acidity regulator (Nakao et al., 1997; Klein et al., 2002) to reduce the gastric pH, inhibit harmful bacteria and promote the growth of beneficial bacteria. Biagi et al. (2006) reported that feeding gluconic acid can improve the growth performance of piglets after weaning. With large-scale production of GOD by fermentation, it is possible to achieve commercial application of GOD in the feed industry (Gao et al., 2012). The researchers' previous study showed that the best dosage of GOD for growth performance improvement of pigs was 100 $\mathrm{U} / \mathrm{kg}$ diet (Tang et al., 2013). Therefore, in the present study $100 \mathrm{U} \mathrm{GOD} / \mathrm{kg}$ was supplemented into a maizesoybean meal diet. The results confirmed that GOD has positive effects on the weight gain and feed conversion efficiency of piglets.

The effects of GOD supplementation in diets on blood parameters are presented in Table 3. The researchers compared 11 parameters between the control and treatment groups and found significant differences in $\mathrm{T}_{3}, \mathrm{~T}_{4}$ and $\mathrm{GH}$ concentrations $(P<0.05)$. Pigs fed GOD-supplemented diets had higher concentrations of $T_{3}(0.97 \mathrm{ng} / \mathrm{mL}$ vs. $0.82 \mathrm{ng} / \mathrm{mL}), T_{4}(6.79 \mu \mathrm{g} / \mathrm{dL}$ vs. $5.45 \mu \mathrm{g} / \mathrm{dL})$ and $\mathrm{GH}(3.81 \mathrm{ng} / \mathrm{mL}$ vs. $3.35 \mathrm{ng} / \mathrm{mL}$ ) in the serum than those fed the control diet. Other blood parameters had a few improvements by supplementing the control diet with GOD. However, no significant differences $(P>0.05)$ were observed. 
Table 2 Effects of glucose oxidase (GOD) supplementation on the growth performance of piglets ${ }^{\mathrm{a}}$

\begin{tabular}{|c|c|c|c|c|}
\hline \multirow{2}{*}{ Items } & \multicolumn{2}{|c|}{ Diet $^{b}$} & \multirow{2}{*}{ SEM } & \multirow{2}{*}{$P$-value } \\
\hline & Control & Control + GOD & & \\
\hline Initial weight (kg) & 7.2 & 7.2 & 0.118 & 0.832 \\
\hline Final weight $(\mathrm{kg})$ & $19.3^{c}$ & $20.6^{d}$ & 0.416 & 0.039 \\
\hline$A D G(g / d)$ & $341^{\mathrm{c}}$ & $382^{d}$ & 18 & 0.031 \\
\hline ADFI (g/d) & 666 & 671 & 32 & 0.712 \\
\hline FCR $(g / g)$ & $1.94^{\mathrm{c}}$ & $1.76^{\mathrm{d}}$ & 0.039 & 0.008 \\
\hline
\end{tabular}

\footnotetext{
${ }^{a}$ Average initial weight of pigs was weighed after the 7-d adaptation period, and the trial lasted 5 weeks. Data are means of four replicates of 14 pigs per replicate pen.

ADG: average daily gain; ADFI: average daily feed intake on a DM basis; FCR: feed conversion ratio.

${ }^{\mathrm{b}}$ Glucose oxidase provided $100 \mathrm{U}$ per kg diet

${ }^{\mathrm{c}, \mathrm{d}}$ Mean values within a row with different superscripts are significant difference $(P<0.05)$.
}

Triiodothyronine and thyroxine are tyrosine-based hormones produced by the thyroid gland, and plasma $T_{4}$ can be converted into $T_{3}$ (Sterling et al., 1970). Thyroid hormones have profound effects on important physiological processes such as development and growth (Visser, 1990; Namroud et al., 2010) and regulation of metabolism (Decuypere et al., 1983; 2005). Another key factor is GH, which mainly stimulates growth, cell reproduction and regeneration (Sorensen et al., 1992). Pigs are uniquely sensitive to high levels of $\mathrm{GH}$, which could improve feed conversion and carcass composition (Machlin, 1972). In this experiment, serum $\mathrm{T}_{3}, \mathrm{~T}_{4}$ and $\mathrm{GH}$ concentrations were increased by $13.7 \%$ after GOD supplementation. The mechanism of this effect is not clear. It might be due to gluconic acid or $\mathrm{H}_{2} \mathrm{O}_{2}$ produced by GOD. Brookes et al. (2005) reported that gluconic acid, as an additive, can be used as an acidity regulator, raising agent, antioxidant and chelating agent in food, feed, etc. In the current study, supplementation of GOD increased the concentrations of $\mathrm{T}_{3}, \mathrm{~T}_{4}$ and $\mathrm{GH}$ in serum and promoted the growth and development of piglets, suggesting the beneficial role of GOD in piglet growth.

Table 3 Effects of glucose oxidase (GOD) on the serum parameters of piglets ${ }^{a}$

\begin{tabular}{lcccc}
\hline \multirow{2}{*}{ Items } & \multicolumn{2}{c}{ Diet } & SEM & P-value \\
\cline { 2 - 3 } & Control & Control + GOD & & \\
\hline Glucose $(\mathrm{mmoL} / \mathrm{L})$ & 4.24 & 4.92 & 0.87 & 0.35 \\
Albumin $(\mathrm{g} / \mathrm{L})$ & 30.31 & 31.26 & 1.03 & 0.54 \\
Globulin $(\mathrm{g} / \mathrm{L})$ & 13.76 & 14.22 & 0.95 & 0.42 \\
Albumin/globulin & 2.15 & 2.22 & 0.51 & 0.68 \\
Total protein $(\mathrm{g} / \mathrm{L})$ & 44.15 & 45.33 & 2.18 & 0.46 \\
Triiodothyronine $\left(\mathrm{T}_{3}, \mathrm{ng} / \mathrm{mL}\right)$ & $0.82^{\mathrm{c}}$ & $0.97^{\mathrm{d}}$ & 0.06 & 0.04 \\
Thyroxine $\left(\mathrm{T}_{4}, \mu \mathrm{g} / \mathrm{dL}\right)$ & $5.45^{\mathrm{c}}$ & $6.79^{\mathrm{d}}$ & 0.49 & 0.03 \\
Thyroid-stimulating hormone $(\mu / \mathrm{U} / \mathrm{mL})$ & 2.84 & 3.20 & 0.40 & 0.11 \\
Growth hormone $(\mathrm{GH}, \mathrm{ng} / \mathrm{mL})$ & $3.35^{\mathrm{c}}$ & $3.81^{\mathrm{d}}$ & 0.22 & 0.04 \\
Insulin $(\mu / \mathrm{U} / \mathrm{mL})$ & 21.49 & 22.10 & 3.28 & 0.81 \\
Glucagon $(\mathrm{pg} / \mathrm{mL})$ & 258.7 & 271.0 & 26.3 & 0.33 \\
& & & & \\
\hline
\end{tabular}

\footnotetext{
${ }^{a}$ Data are means of four replicates of two pigs per replicate pen.

${ }^{\mathrm{c}, \mathrm{d}}$ Mean values within a row with different superscripts differ significantly $(P<0.05)$.
}

The effects of GOD on faecal microflora of piglets are summarized in Table 4. Pigs fed dietary GOD had lower counts of faecal Salmonella (5.3 Igcfu/g vs. $6.0 \mathrm{lgcfu} / \mathrm{g}, P<0.05)$ than pigs fed the non-GOD diet 
on day 35, but not on day $14(P>0.05)$. The counts of total bacteria and $E$. coli in the treatment group were lower than those of the control group, but the differences were not significant $(P>0.05)$. Lactobacilli counts showed no difference between the groups fed with or without GOD. In the current experiment, faecal pathogenic bacteria counts, especially Salmonella, were lower in the GOD-supplemented diet. The reason is probably that the function of GOD is to act as an antibacterial agent through the production of gluconic acid and $\mathrm{H}_{2} \mathrm{O}_{2}$. Biagi et al. (2006) demonstrated that feeding gluconic acid positively influenced the composition and activity of the intestinal microflora of piglets after weaning. It has been reported that sustained oxidative stress through the maintenance of low concentration of $\mathrm{H}_{2} \mathrm{O}_{2}$ by GOD's continued catalytic activity to be effective against pathogenic bacteria (Dobbenie et al., 1995; Wu et al., 1995). Etemadzadeh et al. (1985) reported that the ability of GOD to kill Streptococcus mutans appears to be enhanced, because the $\mathrm{H}_{2} \mathrm{O}_{2}$ produced by GOD acts as a useful bacteriocide. Tiina \& Sandholm (1989) reported that the application of the GOD-glucose system in food products inhibited the growth of pathogens such as Salmonella, Bacillus cereus, and Yersinia. Lactobacilli are lactic acid bacteria and commonly considered to have probiotic effects in the gastrointestinal tract of animals (Zhang et al., 2011). Few studies have been performed concerning the effect of GOD on Lactobacilli. The effects of GOD on fermented sausages have shown inhibition of growth of Staphylococcus aureus, whereas GOD did not affect the growth of Lactobacilli. Lactobacilli themselves are known to produce $\mathrm{H}_{2} \mathrm{O}_{2}$ and therefore they are rather resistant to $\mathrm{H}_{2} \mathrm{O}_{2}$ (Klaenhammer, 1982; Attaie et al., 1987). In this study, except for Lactobacilli, pigs fed GOD showed decreased concentrations of bacteria enumerated in contrast to the control. It is likely that GOD and their associated physicochemical effects play a beneficial role in maintaining the intestinal microflora.

Table 4 Effects of glucose oxidase (GOD) on the faecal microflora of piglets ${ }^{a}$

\begin{tabular}{|c|c|c|c|c|}
\hline \multirow{2}{*}{ Items } & \multicolumn{2}{|c|}{ Diet } & \multirow{2}{*}{ SEM } & \multirow{2}{*}{$P$-value } \\
\hline & Control & Control + GOD & & \\
\hline \multicolumn{5}{|c|}{ Total plate count (lgcfu/g) } \\
\hline d 14 & 8.155 & 8.081 & 0.095 & 0.57 \\
\hline d 35 & 8.899 & 8.847 & 0.115 & 0.52 \\
\hline \multicolumn{5}{|c|}{ Escherichia coli (lgcfu/g) } \\
\hline d 14 & 6.203 & 6.127 & 0.112 & 0.48 \\
\hline d 35 & 7.287 & 7.230 & 0.091 & 0.54 \\
\hline \multicolumn{5}{|c|}{ Salmonella (lgcfu/g) } \\
\hline d 14 & 5.263 & 5.115 & 0.107 & 0.22 \\
\hline d 35 & $5.954^{c}$ & $5.300^{d}$ & 0.190 & 0.03 \\
\hline \multicolumn{5}{|c|}{ Lactobacilli (lgcfu/g) } \\
\hline d 14 & 6.189 & 6.175 & 0.036 & 0.71 \\
\hline d 35 & 6.864 & 6.851 & 0.040 & 0.65 \\
\hline
\end{tabular}

\footnotetext{
${ }^{a}$ Data are means of four replicates of three pigs per replicate pen.

c,d Mean values within a row with different superscripts differ significantly $(P<0.05)$.
}

\section{Conclusion}

The results showed that supplementation of GOD to diets promoted growth performance (ADG and feed efficiency), increased the concentrations of growth and development-related hormone $\left(T_{3}, T_{4}\right.$ and $\left.G H\right)$, and improved the faecal microflora of growing piglets. These changes might be attributed to the functional activities of GOD in the gastrointestinal tract, which utilizes $\mathrm{O}_{2}$ and produces $\mathrm{H}_{2} \mathrm{O}_{2}$ and gluconic acid. Further research is needed to determine the effect of dietary GOD supplementation on other parameters of intestinal health.

\section{Acknowledgements}

This work was supported by the National High-Tech Research and Development Programme of China (863 Programme) [2013AA102803] and the 948 programme of the Ministry of Agriculture [2014-S1] and the Special Fund for Agro-Scientific Research in the Public Health of China [201403047] and China Modern Agriculture Research System 
[CARS-42].

\section{References}

Argenzio, R.A., 1992. Pathophysiology of diarrhea. In: Veterinary Gastroenterology. Ed: Anderson, N., Lea and Fabiger, Philadelphia. pp.163-172.

Attaie, R., Whalen, P.J., Shahani, K.M. \& Amer, M.A., 1987. Inhibition of growth of Staphylococcus aureus during production of acidophilus yogurt. J. Food Prot. 50, 224-228.

Bankar, S.B., Bule, M.V., Singhal, R.S. \& Ananthanarayan, L., 2009. Glucose oxidase - An overview. Biotechnol. Adv. 27 , 489-501.

Biagi, G., Piva, A., Moschini, M., Vezzali, E. \& Roth, F.X., 2006. Effect of gluconic acid on piglet growth performance, intestinal microflora, and intestinal wall morphology. J. Anim. Sci. 84, 370-378.

Brookes, G., Neville, C. \& Kniel, B., 2005. The Global GM Market - implications for the European food chain. PG Economics Limited, UK.

Costa, L.B., Luciano, F.B., Miyada, V.S. \& Gois, F.D., 2013. Herbal extracts and organic acids as natural feed additives in pig diets. S. Afr. J. Anim. Sci. 43, 181-193.

Crueger, A. \& Crueger, W., 1990. Glucose transforming enzymes. In: Microbial Enzymes and Biotechnology. Eds: Fogarty, W.M. \& Kelly, C.T., Elsevier, New York. pp. 177-226.

Decuypere, E., Scanes, C.G. \& Kuhn, E.R., 1983. Effects of glucocorticoids on circulating concentrations of thyroxine ( $\left.T_{4}\right)$ and triiodothyronine $\left(\mathrm{T}_{3}\right)$ and on peripheral monodeiodination in pre- and post-hatching chickens. Horm. Metab. Res. 15, 233-236.

Decuypere, E., Van As, P., Van der Geyten, S. \& Darras, V.M., 2005. Thyroid hormone availability and activity in avian species: a review. Domest. Anim. Endocrinol. 29, 63-77.

Dobbenie, D., Uyttendaele, M. \& Debevere, J., 1995. Antibacterial activity of the glucose-oxidase glucose system in liquid whole egg. J. Food Prot. 58, 273-279.

Etemadzadeh, H., Ainamo, J. \& Murtomaa, H., 1985. Plaque growth-inhibiting effects of an abrasive fluoridechlorhexidine toothpaste and a fluoride toothpaste containing oxidative enzymes. J. Clin. Periodontol. 12, 607-616.

Gao, Z., Li, Z., Zhang, Y., Huang, H., Li, M., Zhou, L., Tang, Y., Yao, B. \& Zhang, W., 2012. High-level expression of the Penicillium notatum glucose oxidase gene in Pichia pastoris using codon optimization. Biotechnol. Lett. 34, 507-514.

Hampson, D.J., Hinton, M. \& Kidder, D.E., 1985. Coliform numbers in the stomach and small intestine of healthy pigs following weaning at three weeks of age. J. Comp. Pathol. 95, 353-362.

Hatzinikolaou, D.G. \& Macris, B.J., 1995. Factors regulating production of glucose-oxidase by Aspergillus-niger. Enzyme Microb. Technol. 17, 530-534.

Hatzinikolaou, D.G., Hansen, O.C., Macris, B.J., Tingey, A., Kekos, D., Goodenough, P. \& Stougaard, P., 1996. A new glucose oxidase from Aspergillus niger: Characterization and regulation studies of enzyme and gene. Appl. Microbiol. Biotechnol. 46, 371-381.

Hunter, W.M., 1986. Radioimmunoassay. In: Handbook of Experimental Immunology. Volume 1. Immunochemistry. Ed: Weir, D.M., Blackwell Scientific Publications, London. pp. 1-23.

Jones, P.H., Roe, J.M. \& Miller, B.G., 2001. Effects of stressors on immune parameters and on the faecal shedding of enterotoxigenic Escherichia coli in piglets following experimental inoculation. Res. Vet. Sci. 70, 9-17.

Klaenhammer, T.R., 1982. Microbiological considerations in selection and preparation of lactobacillus strains for use as dietary adjuncts. J. Dairy Sci. 65, 1339-1349.

Klein, J., Rosenberg, M., Markos, J., Dolgos, O., Kroslak, M. \& Kristofikova, L., 2002. Biotransformation of glucose to gluconic acid by Aspergillus niger - study of mass transfer in an airlift bioreactor. Biochem. Eng. J. 10, 197-205.

Machlin, L.J., 1972. Effect of porcine growth hormone on growth and carcass composition of the pig. J. Anim. Sci. 35, 794-800.

Malherbe, D.F., Du Toit, M., Cordero Otero, R.R., Van Rensburg, P. \& Pretorius, I.S., 2003. Expression of the Aspergillus niger glucose oxidase gene in Saccharomyces cerevisiae and its potential applications in wine production. Appl. Microbiol. Biotechnol. 61, 502-511.

Nakao, K., Kiefner, A., Furumoto, K. \& Harada, T., 1997. Production of gluconic acid with immobilized glucose oxidase in airlift reactors. Chem. Eng. Sci. 52, 4127-4133.

Namroud, N.F., Shivazad, M., Zaghari, M. \& Shahneh, A.Z., 2010. Effects of glycine-and glutamic acid supplementation to low protein diets on performance, thyroid function and fat deposition in chickens. S. Afr. J. Anim. Sci. 40, 238-244.

Opwis, K., Knittel, D., Schollmeyer, E., Hoferichter, P. \& Cordes, A., 2008. Simultaneous application of glucose oxidases and peroxidases in bleaching processes. Eng. Life Sci. 8, 175-178.

Pluschkell, S., Hellmuth, K. \& Rinas, U., 1996. Kinetics of glucose oxidase excretion by recombinant Aspergillus niger. Biotechnol. Bioeng. 51, 215-220.

Pluske, J.R., Pethick, D.W., Hopwood, D.E. \& Hampson, D.J., 2002. Nutritional influences on some major enteric bacterial diseases of pigs. Nutr. Res. Rev. 15, 333-371.

Rasiah, I.A., Sutton, K.H., Low, F.L., Lin, H.M. \& Gerrard, J.A., 2005. Crosslinking of wheat dough proteins by glucose oxidase and the resulting effects on bread and croissants. Food Chem. 89, 325-332.

Reed, W.M., Olander, H.J. \& Thacker, H.L., 1985. Studies on the pathogenesis of Salmonella heidelberg infection in weanling pigs. Am. J. Vet. Res. 46, 2300-2310.

SAS, 2004. Statistical Analysis Systems User's Guide. SAS Institute Inc., Cary, N.C., USA.

Schwartz, K.J., 1999. Salmonellosis. In: Diseases of Swine (8th ed). Eds: Straw, B.E., Allaire, S.D., Mengeling, W.L. \& 
Taylor, D.J., Blackwell Science, Oxford. pp. 535-551.

Seifu, E., Donkin, E.F. \& Buys, E.M., 2004. Application of the lactoperoxidase system to improve the quality of goat milk cheese. S. Afr. J. Anim. Sci. 34, 184-187.

Sorensen, M.T., Chaudhuri, S., Louveau, I., Coleman, M.E. \& Etherton, T.D., 1992. Growth hormone binding proteins in pig adipose tissue: number, size and effects of $\mathrm{pGH}$ treatment on $\mathrm{pGH}$ and bGH binding. Domest. Anim. Endocrinol. 9, 13-24.

Sterling, K., Brenner, M.A. \& Newman, E.S., 1970. Conversion of thyroxine to triiodothyronine in normal human subjects. Science 169, 1099-1100.

Tang, H., Gao, X., Yao, B., Li, X. \& Wang, X., 2013. Study on feed effects of glucose oxidase applied in piglets. China Feed 19, 21-23.

The Ministry of Agriculture of P R China, 2004. Feeding Standard of Swine of P. R. China. Natl. Stand. NY/T 65-2004. Beijing, P. R. China.

Tiina, M. \& Sandholm, M., 1989. Antibacterial effect of the glucose oxidase-glucose system on food-poisoning organisms. Int. J. Food Microbiol. 8, 165-174.

Vaughn, S.E., 2012. Review of the third edition of the guide for the care and use of agricultural animals in research and teaching. J. Am. Assoc. Lab. Anim. Sci. 51, 298-300.

Visser, T.J., 1990. Importance of deiodination and conjugation in the hepatic metabolism of thyroid hormone. In: The Thyroid Gland. Ed: Greer, M.A., Raven Press, New York. pp. 255-283.

Wu, G., Shortt, B.J., Lawrence, E.B., Levine, E.B., Fitzsimmons, K.C. \& Shah, D.M., 1995. Disease resistance conferred by expression of a gene encoding $\mathrm{H}_{2} \mathrm{O}_{2}$-generating glucose oxidase in transgenic potato plants. Plant Cell 7 , 1357-1368.

Zhang, J., Deng, J., Wang, Z., Che, C., Li, Y.F. \& Yang, Q., 2011. Modulatory effects of Lactobacillus salivarius on intestinal mucosal immunity of piglets. Curr. Microbiol. 62, 1623-1631. 